\title{
Detection of IG and TCR Monoclonality as a Molecular Marker in Acute Hematopathies
}

\author{
IRINA CEZARA VACAREAN TRANDAFIR ${ }^{1,2}$, IULIU CRISTIAN IVANOV ${ }^{1}$, LOREDANA MIHAIELA DRAGOS ${ }^{1,2}$, \\ AMALIA ANDREA TITIEANU 3 ,4*, DUMITRU COJ OCARU2,5 \\ 1Regional Institute of Oncology, Reaserch Center Transcend, Department of Molecular Genetics, 2-4 General Henri Mathias \\ Berthelot Str., 700483, Iasi, Romania \\ 2Alexandru Ioan Cuza University, Department of Biochemistry, 11 Carol I Blvd., 700506, Iasi, Romania \\ ${ }^{3}$ Regional Institute of Oncology, Department of Hematology, 2-4 General Henri Mathias Berthelot Str., 700483, lasi, Romania \\ ${ }^{4}$ Grigore T. Popa University of Medicine and Pharmacy, Department of Physiopathology, 16 Universitatii Str., 700115, Iasi, Romania \\ ${ }^{5}$ Academy of Romanian Scientists, 54 Splaiul Independenei Str. 050094, Bucharest, Romania
}

\begin{abstract}
The aim of this study was to use clonal gene rearrangements assays to discriminate between oligo-clonal or polyclonal reactive processes in cases that presented difficulty in diagnosis of $B$ or T-acute lymphoblastic leukemia $(A L L)$ due to abnormal phenotypes detected by flow-cytometry. Monoclonal B $/ T$ cells were detected by rearrangements of immunoglobulin (Ig) and T-cell receptors (TCR) in 10 patients. After DNA extraction from peripheral blood, multiplex PCR was used to amplify the $\mathrm{Ig} / T C R$ gene rearrangements followed by capillary electrophoresis, according to BIOMED 2 conditions. The evaluation of the results was carried out in the clinical and interdisciplinary (histomorphological, molecular and flow-cytometric) context. The presence of clonal rearrangements may indicate the existence of two neoplastic processes or a single clone with two gene rearrangements - one productive and one non-productive on the two alleles, considering the use of genomic DNA. By fragment analysis we identified $B / T$ cells gene recombinations using multiplex $P C R$ with primer sets that target each type of gene family. Using these molecular markers we can discriminate between monoclonal/polyclonal cells and follow a clonal marker throughout the disease evolution.
\end{abstract}

Keywords: ALL, Ig/TCR, gene rearrangement, BIOMED2, monoclonal

Acute lymphoblastic leukemia (ALL) includes a heterogeneous group of malignant disorders which originate from different significant genetic lesions in $B$ and T progenitor cells, including mutations that lead to phasespecific developmental arrestand interfere with the ability of self-renewal, resulting in clonal expansion of immature progenitor cells [1]. Presently, discriminating between reactive processes and malignant lymphoid proliferations implies a combination of clinical aspects, immunophenotype, cyto/histomorphology and detection of chromosomal abnormalities. Nevertheless, these methods of diagnosis remain challenging in $10-15 \%$ of cases of lymphoproliferative disorders and clonality assessments are frequently required to validate diagnostic presumptions. The most part of lymphoid malignancies (>98\%) contain identical (clonal) rearrangements of the immunoglobulin (Ig) and/or T-cell receptor (TCR) genes that can be used as clonality markers, along with other well-defined chromosomal abnormalities that can be found in $25-30 \%$ of cases [2].

Identifying the molecular events that substantiate the process of leukemic transformation has provided valuable information about clinically significantmolecular markers, both for the identification of ALL subgroups and for the monitoring of minimal residual disease (MRD) $[3,4]$. For ALL in particular, immunoglobulin (Ig) and T-cell receptor (TCR) gene rearrangements stand out as the most widely applied targets used as molecular markers for clonality and MRD detection [5]. These Ig and TCR rearrangements descend from the earliest stages of $B$ and T-cell development onwards [6]. During early lymphoid differentiation, genes encoding the Ig and TCR molecules are formed by stepwise rearrangement of variable $(\mathrm{V})$, diversity (D) and joining (J) gene segments, process referred to as V(D)] recombination [6, 7]. Random coupling between one of many $V$, $D$ and I gene segments results in the formation of an unique $V(D)$ J exon that encodes the actual antigen binding site of the Ig/TCR chain [8]. As a consequence, each lymphocyte has a unique antigen receptor molecule on its membrane. Cancer cells are the result of a single malignantly transformed cell (a single lymphoid precursor with a unique immunoglobulin and/or T-cell receptor); therefore, these cells are clonally related. Hence, identical rearrangements are not derived from multiple independently generated cells, but rather reflect the clonal nature of the involved cell population.

The development of PCR-based approaches in the last years has facilitated the complex characterization and classification of malignant diseases, patient stratification and monitoring of minimal residual disease (MRD) [9]. Following flow-cytometric analysis of $\mathrm{T}$ or $\mathrm{B}$-cell populations, PCR-based clonality assays are requested to identify whether the populations of cells are derived from clonal or polyclonal expansions $[10,11]$. These PCR clonality strategies targeting immunoglobulin genes developed by the EuroClonality/ BIOMED-2 consortium [12] contribute to an accurate diagnosis of $\mathrm{B}$ or T-cell malignancies in cases when atypical B or T lymphocytes are detected by flow-cytometry. The method ensures clonality detection in virtually all $\mathrm{B}$ and T-cell lymphoproliferative disorders [13, 14]; however, clonality detection does not always imply malignancy, as some reactive processes may contain clonal lymphocyte populations [15]. It should be emphasized that the context in which clonality is observed is utterly important, and although clonality is strongly predictive of neoplasia in certain situations, it is not sufficient to demonstrate a neoplastic hypothesis or malignancy; therefore, these 
analysis should always be interpreted in the context of clinical, morphological and immunophenotypic data [12].

\section{Experimental part}

\section{Materials and methods}

During a six months period, 10 patients of both genders aged between 19 and 88 years were selected for monclonality testing based on abnormal phenotypes detected by flow-cytometry that could not conclude the nature of the cell populations. Analyzes were approved by the institution's ethics committee and written consent was obtained from each patient according to hospital policy.

Peripheral blood was collected from the patients for genomic DNA extraction and for monoclonality evaluation. Genomic DNA was extracted using W izard Genomic DNA Purification Kit(Promega Corporation, Madison, Wisconsin, USA), according to the manufacturer protocol. The obtained DNA was quantified using a ND-2000 Spectrophotometer (NanoDrop Technologies Inc., Wilmington, DE, USA). Samples with 200-500 ng DNA were amplified by multiplex polymerase chain reaction (PCR).

For the clonality analysis, rearrangements of IGH, IHK, TCRB and TCRG gene were amplified using the IGH/IGK, TCRB/TCRG Gene Clonality Assay kits (InvivoScribe ${ }^{\circledR}$, San Diego, California, USA) and IGH/IGK, TCRB/TCRG Rearrangements Molecular Analysis kits (Master Diagnostica, Granada, Spain) (12). PCR amplifications were performed using fluorescently labelled Euroclonality/ BIOMED-2 primers (B-cell: IGH FR1, IGH FR2, IGH FR3, IGK V-J, IGK V-Kde; T-cell: TCRB V-J 1+2, TCRB V-J 2, TCRB D-J 1+2, TCRG V(1-8,10)-J, TCRG V(9,11)-J (Invivoscribe, San Diego, California, USA) according to the guidelines of the manufacturer and the Euroclonality/ BIOMED-2 consortium. Capillary electrophoresis was carried out with an ABI 3500 Genetic Analyzer (Applied Biosystems ${ }^{\circledR}$, Foster City, CA, USA) and only reproducible peaks with a range higher of 50 relative fluorescence units (RFU) were considered; a fluorescent LIZ (GeneScan ${ }^{m} 500$ LIZ $^{\circledR}$, Thermo Fisher Scientific, Applied Biosystems ${ }^{\circledR}$ ) labeled 500 base size standard was used. During the runs, a positive control and a negative control were included and the analyzes were performed in duplicate in all cases; the results were interpreted using the Gene Mapper software (Thermo Fisher Scientific, Applied Biosystems ${ }^{\circledR}$, Foster City, CA, USA).

\section{Results and discussions}

Most of B cell neoplasms have clonal IGH (VDJ) and IGK gene rearrangements with definite complementarity of clonality detection [16]. Furthermore, the detection of both a clonal IGH and IGK rearrangement represents itself a confirmation of clonality. As well, the majority of T cell neoplasms have clonal TCRG and TCRB gene rearrangements [5].

In the $10 \mathrm{~B} / \mathrm{T}$-ALL patients analyzed at diagnosis, clonality assays revealed $10 \%$ polyclonal, $90 \%$ monoclonal (50\% monoclonal with polyclonal background and 40\% biclonal/biallelic). Polyclonal populations result in multiple peaks with normal Gaussian' distribution, whereas a monoclonal population usually results in a single peak of an expected size (fig. 1).

Each individual PCR reaction is first viewed independently in duplicate analysis and with knowledge of morphological and/or immunophenotypical findings when available. Each result is classified as a clonal, non-clonal, abnormal, or polyclonal peak. Clonal patterns are defined as the presence of one or two reproducible peaks that distinctly dominate the polyclonal background. An exact numeric limit is not established, but it is noted that clonal peaks usually are at least 2-3 times the height of the polyclonal background [17]. An abnormal peak is defined as showing an aberrant prominent peak compared with the control that is reproducible in duplicate but does not clearly dominate the polyclonal background [18]. Last, a nonclonal pattern lacks clonal or abnormal peaks and includes oligo-clonal and polyclonal, as well as cases exhibiting no specific amplifications.

Multiplex PCR-based clonality testing has become a universal standard $[19,20]$, technically easy to perform. Nevertheless, to avoid misinterpretation of the data, a carefully evaluation of histopathologic and molecular findings is necessary for reaching an accurate interpretation of the oligo-/monoclonality results.

Apart from the interdisciplinary context of interpretation, repeated analyses on the same sample, on independent second DNA isolations and/or on a related sample, are necessary to check for consistency of the pattern. In addition, the isolated DNA must be of good quality and high concentration (between 200-500 ng); also it is recommended that all assays must be performed in duplicate in order to establish reproducibility of clonality profiles and products, which is crucial for the proper detailed molecular interpretation [11, 21-24].

The percentage of suspected cells and the percentage of normal $B$ and $T$ lymphocytes optained from histopathology and/or flow cytometry are substantial parameters to be regarded for estimating the relevance of the $\mathrm{lg} / T C R$ clonality findings. Thereby, the findings of weak clonal signals in a background of polyclonal signals are hardly compatible with a large suspect cell population and, therefore, such $\mathrm{lg} / \mathrm{TCR}$ discoveries should be interpreted with prudence [15].

A major and intricate interpretation issue concerns the question whether the detection of multiple clonal patterns corresponds to biclonality. While biclonal malignancies can exist, the results must be interpreted with caution and immunobiologic and technical explanations should first be taken into account, as they may be responsible for the multiple clonal signals that can take place. To begin with, $B$ and T cells hold two distinctchromosomes, thus biallelic rearrangements are more likely to appear than biclonality. On careful consideration, the literature also illustrates in cases of multiple clonal signals, biclonality being mainly the exception than the rule $[13,25]$. The two exemplified cases of biclonal/biallelic peaks that were analyzed (fig.1, Frame 1 and 3) sustain the former affirmation that there are two alleles involved rather than two distinct clones of malignant cells or a single clone with two rearrangements, taking into account the provided flow-cytometric data.

Oligo-clonality was determined in one sample (fig.1, Frame 2) consistent with the clinical and flow-cytometric data that revealed a normal distribution of cell populations. Also, the polyclonal background seen in some samples (fig.1, Frame 3 and 4) emerged due to the coexistence of an expanding monoclonal cell population with the typical expected cell populations.

Depending on primer positions and the extent of nucleotide insertion at the junctions, there may appear a non-specific product of 211 nucleotides that does not affect the results, since it is out of the product size range (FR3$\mathrm{JH}: 100-170 \mathrm{bp}$ ) and also seen in the control (Fig.1, Frame $1 \mathrm{C}, 2 \mathrm{C}$ and $\mathrm{3C}$ ). This product is obtained because of primer annealing to downstream $\mathrm{JH}$ gene rearrangements [12, 23]. 


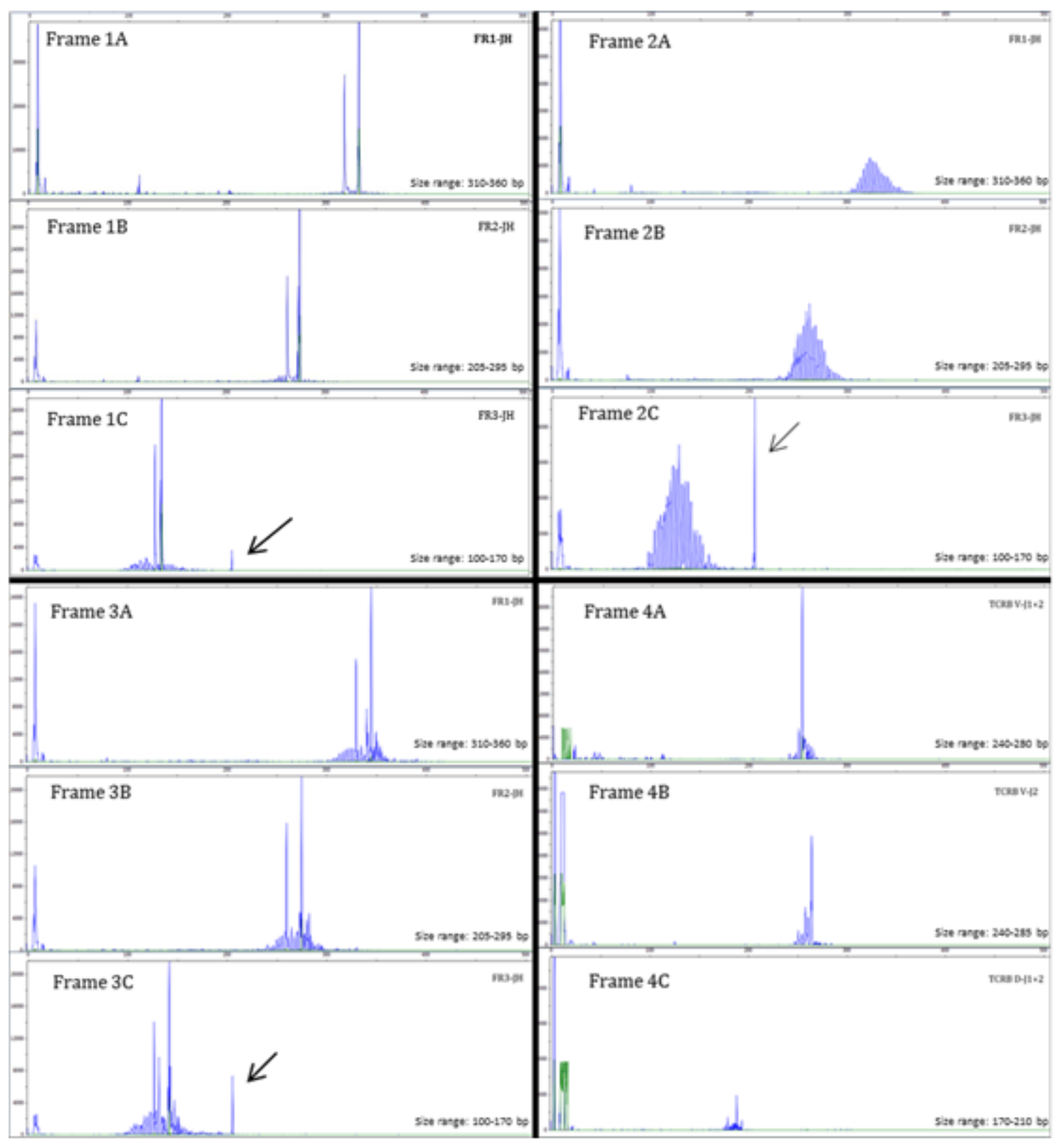

Fig. 1. Representative images of clonal and polyclonal patterns obtained with the IGH (FR1-JH, FR2-JH, FR3-J H) and TCRB (V-J 1+2, V-J2, D-J 1+2) primer sets. Biclonal/biallelic products are highlighted in Frame 1, polyclonal products in Frame 2, biclonal/biallelic products with polyclonal background in Frame 3 and a monoclonal peak with polyclonal background is shown in Frame 4. A non-specific 211 nucleotide

\section{Conclusions} peak (marked by arrow) appears in Frame 1C, $2 \mathrm{C}$ and $3 \mathrm{C}$ (FR3-J H primers)

Aside from repeated analyses on the sample, careful consideration on good DNA quality and concentration, a thorough (re)assessment of histopathological and molecular findings is necessary for reaching a adequate evaluation of the oligo-/monoclonality results.

A close collaboration between departments of molecular biology, pathology, hematology and immunology ensures integration of all existing data in order to obtain the most adequate conclusions and the most reliable diagnosis.

\section{References}

1.BESBES, S., HAMADOU, W.S., BOULLAND, M.L., YOUSSEF, Y.B., ACHOUR, B., REGAIEG, H., KHELIF, A., FEST, T., SOUA, Z., Braz. J. Med. Biol. Res., 50, no. 1, 2017, p. 7.

2.VAN DONGEN, J. J.M., W OLVERS-TETTERO, I.L.M., Clin. Chim. Acta, 198, no.1-2, 1991, p. 93.

3.BRUGGEMANN, M., SCHRAUDER, A., RAFF, T., PFEIFER, H., DWORZAK, M., OTTMANN, O.G., ASNAFI, V., BARUCHEL, A., BASSAN,
R., BENOIT, Y., BIONDI, A., CAVÉ, H., DOMBRET, H., FIELDING, A.K., FOÀ, R., GÖKBUGET, N., GOLDSTONE, A.H., GOULDEN, N., HENZE, G., HOELZER, D., JANKA-SCHAUB, G.E., MACINTYRE, E.A., PIETERS, R., RAMBALDI, A., RIBERA, J-M., SCHMIEGELOW, K., SPINELLI, O., STARY, J., VON STACKELBERG, A., KNEBA, M., SCHRAPPE M., VAN DONGEN, J.J.M., Leukemia, 24, no. 3, 2010, p. 521.

4.CAMPANA, D., ASH Educ. Program. Book, 1, 2010, p. 7.

5.GROENEN, P.] ., VAN RAAI], A., VAN ALTENA, M.C., ROMBOUT, P.M., VAN KRIEKEN, J.H. J. Hematop., 5, no. 1-2, 2012, p. 17.

6.KINDT, T.J., GOLDSBY, R.A., OSBORNE, B.A., KUBY, J. Macmillan, 2007, p. 105.

7.MURPHY, K., WEAVER, C., Garland Science, 2016, p. 173.

8.TONEGAWA, S., Nature, 302, no. 5909, 1983, p. 575.

9.KAVIANPUR, M., SHAHJAHANI, M., JASEB, K., KASAR, S., SAKI, N., Comp. Clin. Path., 26, no. 2, 2017, p. 269.

10.MCCLURE, R.F., KAUR, P., PAGEL, E., OUILLETTE, P.D., HOLTEGAARD, C.E., TREPTOW, C.L., KURTIN, P.J ., Leukemia, 20, no. 1,2006, p. 176. 
11.LANGERAK, A.W., GROENEN, P.J ., BRUGGEMANN, M., BELDJ ORD, K., BELLAN, C., BONELLO, L., BOONE, E., CARTER, G.I., CATHERWOOD, M., DAVI, F., DELFAU-LARUE, M-H., DISS, T., EVANS, P.A.S., GAMEIRO, P., GARCIA SANZ, R., GONZALEZ, D., GRAND, D., HAKANSSON, Å., HUMMEL, H LIU, L LOMBARDIA, E A MACINTYRE, B J MILNER, S MONTES-MORENO, M., SCHUURING, E., SPAARGAREN, M., HODGES E., VAN DONGEN, J J. M., Leukemia, 26, no. 10, 2012, p. 2159.

12.VAN DONGEN, J.J.M., LANGERAK, A.W., BRUGGEMANN, M., EVANS, P.A.S., HUMMEL, M., LAVENDER, F.L., DELABESSE, E., DAVI, F., SCHUURING, E., GARCIA-SANZ, R., VAN KRIEKEN, J.H.J.M., DROESE, J., GONZALEZ, D., BASTARD, C., WHITE, H.E., SPAARGAREN, M., GONZALEZ, M., PARREIRA, A., SMITH, J.L., MORGAN, G.J ., KNEBA, M., MACINTYRE, E.A., Leukemia, 17, no. 12, 2003, p. 2257.

13.LANGERAK, A.W., GROENEN, P.J ., VAN KRIEKEN, J.H., VAN DONGEN, J.J.M., Expert Opin. Med. Diagn., 1, no. 4, 2007, p.451.

14.EVANS, P.A.S., POTT, C., GROENEN, P.J., SALLES, G., DAVI, F., BERGER, F., GARCIA, J.F., VAN KRIEKEN, J.H.J.M., PALS, S., KLUIN, P.H., SCHUURING, E., SPAARGAREN, M., BOONE, E., GONZALEZ, D., MARTINEZ, B., VILLUENDAS, R., GAMEIRO, P., DISS, T.C., MILLS, K., MORGAN, G.J ., CARTER, G.I., MILNER, B.J., PEARSON, D., HUMMEL, M., JUNG, W., OTT, M., CANIONI, D., BELDJORD, K., BASTARD, C., DELFAU-LARUE, M.H., VAN DONGEN, J. J.M., MOLINA, T.J ., CABEÇADAS, J., Leukemia, 21, no. 2, 2007, p. 207.

15.LANGERA, A.W., MOLINA, T.J ., LAVENDER, F.L., PEARSON, D., FLOHR, T., SAMBADE, C., SCHUURING, E., AL SAATI, T., VAN DONGEN, J.J.M., VAN KRIEKEN, J.H.J.M., Leukemia, 21, no. 2, 2007, p. 222. 16.BRUGGEMANN, M., WHITE, H., GAULARD, P., GARCIA-SANZ, R., GAMEIRO, P., OESCHGER, S., J ASANI, B., OTT, M., DELSOL, G., ORFAO, A., TIEMANN, M., HERBST, H., LANGERAK, A.W., SPAARGAREN, M., MOREAU, E., GROENEN, P. .T.A., SAMBADE, C., FORONI, L., CARTER, G.I., HUMMEL, M., BASTARD, C., DAVI, F., DELFAU-LARUE, M-H., KNEBA, M., VAN DONGEN, J.J.M., BELDJ ORD, K., MOLINA, T.J., Leukemia, 21, no. 2, 2007, p. 215.
17.KUO, F.C., HALL, D., LONGTINE, J.A., J. Mol. Diagn., 9, no. 1, 2007, p. 12.

18.PARK, I. ., BENA, J., COTTA, C.V., HSI, E.D., J EGALIAN, A.G., ROGERS, H.J., TUBBS, R.R., WANG, L., COOK, J.R., J. Clin. Pathol., 67, 2014, p. 1093.

19.LIU, H., BENCH, A.J ., BACON, C.M., PAYNE, K., HUANG, Y., SCOTT, M.A., ERBER, W.N., GRANT, J.W., DU, M.-Q., Br. J. Haematol., 138, no. 1, 2007, p. 31.

20.CHEN, Y.L., SU, I.J ., CHENG, H.Y., CHANG, K.C., LU, C.C., CHOW, N-H., HO, C-L., HUANG, W., Leuk. Lymphoma, 51, no. 4, 2010, p. 650. 21.VAN KRIEKEN, J.H.J., LANGERAK, A.W., MACINTYRE, E.A., KNEBA, M., HODGES, E., GARCIA SANZ, R., MORGAN, G.J ., PARREIRA, A., MOLINA, T.J ., CABECADAS, J., GAULARD, P., JASANI, B., GARCIA, J.F., OTT, M., HANNSMANN, M.L., BERGER, F., HUMMEL, M., DAVI, F., BRUGGEMANN, F L LAVENDER, E SCHUURING, P A SEVANS, H WHITE, M., SALLES, G., GROENEN, P.j.T.A., GAMEIRO, P., POTT, C.H., VAN DONGEN, J.J.M., Leukemia, 21, no. 2, 2007, p. 201.

22.LANGERAK, A.W., VAN DONGEN, J.J.M., J. Hematop., 5, no. 1-2, 2012, p. 35.

23.ROTHBERG, P.G., LANGERAK, A.W., VERHAAF, B., VAN DONGEN, J.J.M, RICHARD BURACK, W., JOHNSON, M.D., SLATE, D., LAUGHLIN, T.S., PAYNE,K., FIGUEIREDO, L., BANDOH, B.N., YAN, Q., BACON, C.M., WRIGHT, P., BENCH, A., DU, M-Q., LIU, H., J. Hematop., 5, no. $1-2,2012$, p. 57.

24.HARRIS, S., BRUGGEMANN, M., GROENEN, P.J., SCHUURING, E., LANGERAKE, A.W., HODGES, E., J. Hematop., 5, no. 1-2, 2012, p. 91. 25.SANCHEZ, M.L., ALMEIDA, J., LOPEZ, A., SAYAGUES, J.M., RASILLO, A., SARASQUETE, E.A., BALANZATEGUI, A., TABERNERO, M.D., DIAZMEDIAVILLA, J., BARRACHINA, C., PAIVA, A., GONZALEZ, M., SAN MIGUEL, J.F., ORFAO, A., Haematologica. 91, no. 3, 2006, p. 331.

Mauscript received: 17.10 .2018 